\title{
Administration of extra-amniotic arachidonic acid and the suppression of uterine prostaglandin synthesis during pregnancy in the rhesus monkey
}

\author{
J. S. Robinson, R. L. K. Chapman*, J. R. G. Challis†, M. D. Mitchell \\ and G. D. Thorburn $\ddagger$
}

University of Oxford, Nuffield Department of Obstetrics and Gynaecology and the Nuffield Institute for Medical Research, Headley Way, Headington, Oxford, U.K.

\begin{abstract}
Summary. After extra-amniotic treatment of pregnant rhesus monkeys premature parturition was induced in 4 given $2.5 \mathrm{mg}$ PGE-2; none of the 4 monkeys given $100 \mathrm{mg}$ arachidonic acid were affected. The concentrations of PGE, PGF or 13,14-dihydro-15oxo-PGF did not change after arachidonic acid treatment, but all increased after PGE2. It is suggested that the availability of substrate, arachidonic acid, is not a major factor governing the control of PG synthesis but that the latter is suppressed during pregnancy.
\end{abstract}

\section{Introduction}

In the rhesus monkey prostaglandin production appears to be essential for normal parturition because administration of a prostaglandin synthetase inhibitor, indomethacin, results in prolonged pregnancy (Novy, Cook \& Manaugh, 1974; Manaugh \& Novy, 1976). Conversely, intramuscular or subcutaneous injection of prostaglandin (PG) causes premature parturition (Kirton, Pharriss \& Forbes, 1970; Kirton, Duncan, Oesterling \& Forbes, 1971; Challis, Davies, Benirschke, Hendrickx \& Ryan, 1974). During the last 5 days before parturition the concentrations of PGF and 13,14-dihydro-15oxo-prostaglandin F (PGFM) increase four-fold in amniotic fluid in parallel with the changes in oestrone and oestrone sulphate (Mitchell, Patrick, Robinson, Thorburn \& Challis, 1976). Although the sites of PG synthesis in the uterus of the rhesus monkey are at present unknown; it has been suggested that the major sites of PG production in the human uterus are the decidua and fetal membranes (Karim, Hillier \& Devlin, 1968; Gustavii, 1973; Keirse \& Turnbull, 1976; Schwarz, Schultz, MacDonald \& Johnston, 1976). Furthermore, it has been proposed that the rate-limiting step in the regulation of PG synthesis and hence the onset of labour, is the availability of arachidonic acid (Kunze \& Vogt, 1971; Gustavii, 1973; Challis, Robinson \& Thorburn, 1976).

The present study was designed to test this hypothesis by supplying arachidonic acid extraamniotically to the decidua and membranes of the rhesus monkey.

\section{Materials and Methods}

Twelve (12) female rhesus monkeys (Macaca mulatta) were each paired with a male for 3 days beginning on Day 10 of the menstrual cycle (Day 1 = first day of menstrual bleeding). Vaginal smears were taken daily until mating was confirmed by the presence of spermatozoa. The female was then caged individually. When the monkeys were 131-149 days pregnant, anaesthesia was induced by intramuscular injection of $20 \mathrm{mg}$ phencyclidine hydrochloride (Sernylan: Bioceutic Laboratories, Missouri, U.S.A.). The monkey was placed in the lithotomy position and the cervix exposed. The

\footnotetext{
* Present address: University College Hospital, Gower Street, London WC1 E6AU, U.K.

$\dagger$ Present address: McGill University, Royal Victoria Hospital, Women's Pavilion, 687 Pine Avenue West, Montreal PQ, Canada.

$\ddagger$ Present address: University of Queensland, Department of Physiology, St. Lucia, Brisbane, Queensland 4067,
} Australia. 
course of the cervical canal was identified by careful probing with a large pair of curved artery forceps, thus leading to dilatation of the internal os of the cervix, dislocation of the mucous plug and usually slight bleeding. An infant feeding catheter (No. 8 gauge: Portex, Hythe, Kent) was inserted through the internal os to leave $20 \mathrm{~cm}$ of the catheter beyond the cervix. Arachidonic acid (Sigma, London) 1 or $100 \mathrm{mg}$, was taken up in $0.5 \mathrm{ml}$ ethanol, diluted to $10 \mathrm{ml}$ with Hyskon $(32 \%(\mathrm{w} / \mathrm{v})$ dextran of mol. wt 70000 and $10 \%(\mathrm{w} / \mathrm{v})$ dextrose: Pharmacia, London) and injected slowly extra-amniotically in 6 animals (Nos 1-6). Four (4) other monkeys (Nos 7-10) were given an extra-amniotic injection of $2.5 \mathrm{mg} \mathrm{PGE}-2$ (Prostin $\mathrm{E}_{2}$ : Upjohn, Crawley, Sussex) in $10 \mathrm{ml}$ Hyskon and 2 animals (Nos 11 and 12) received $10 \mathrm{ml} \mathrm{Hyskon}$ by the same route.

Monkeys 5, 6, 9 and 10 also had a catheter (o.d. $1.02 \mathrm{~mm}$, epidural cannula; Portex, Hythe, Kent) placed in the amniotic sac by means of a 16-gauge Tuohy needle. Amniotic fluid ( $2 \mathrm{ml})$ was collected before and $5 \mathrm{~min}$ after placement of the extra-amniotic catheter; maternal saphenous vein blood ( $3 \mathrm{ml}$ ) was obtained by venepuncture immediately after each amniotic fluid sample. After injection of $10 \mathrm{ml}$ Hyskon (with or without arachidonic acid or PGE-2) blood samples were collected at $30 \mathrm{~min}, 24$ and $48 \mathrm{~h}$ and amniotic fluid was collected at $30 \mathrm{~min}$ and $48 \mathrm{~h}$. The blood samples were collected into chilled heparinized tubes, centrifuged at $1500 \mathrm{~g}$ and $4^{\circ} \mathrm{C}$ for $15 \mathrm{~min}$ and stored at $-15^{\circ} \mathrm{C}$. Amniotic fluid was collected into chilled tubes and stored at $-15^{\circ} \mathrm{C}$ until assayed.

The concentrations of PGE, PGF and PGFM were measured in the samples of maternal plasma and amniotic fluid by radioimmunoassay procedures which have been evaluated and described in detail elsewhere (Mitchell et al., 1976, 1978a; Mitchell \& Flint, 1978). The extraction efficiencies ranged from $65-90 \%$. The solvent blanks were $<10 \mathrm{pg} / \mathrm{ml}$ for each assay and the mean interassay coefficients of variation were $9.8,13.9$ and $11.8 \%$ for PGE, PGF and PGFM respectively. In each assay the minimum sensitivity tested was $10 \mathrm{pg} /$ tube and was always significantly different from zero.

\section{Results}

After the injection the cervix was inspected for leakage of Hyskon. Significant leakage (3-5 ml) was observed in two animals receiving PGE-2 (Nos 7 and 10) and was associated with uterine activity detected by abdominal palpation; no leakage was observed in the others. Leakage of amniotic fluid did not occur. All 4 monkeys injected with PGE-2 produced young within 2-5 days; 2 of the infants were dead. In contrast, the controls given Hyskon alone and the monkeys injected with arachidonic acid gave birth normally at term, 13-30 days after injection, and all the young were alive and survived (Table 1).

Table 1. The treatments and responses of the rhesus monkeys

\begin{tabular}{|c|c|c|c|c|c|}
\hline \multirow[b]{2}{*}{ Monkey } & \multirow[b]{2}{*}{ Treatment* } & \multicolumn{2}{|c|}{ Day of pregnancy } & \multicolumn{2}{|c|}{ Young } \\
\hline & & At injection & At parturition & Weight (g) & Sex \\
\hline 1 & $1 \mathrm{mg} \mathrm{AA}$ & 144 & 167 & 442 & 우 \\
\hline 2 & $1 \mathbf{m g} \mathbf{A A}$ & 142 & 165 & 364 & 우 \\
\hline 3 & $100 \mathrm{mg} A A$ & 144 & 161 & 441 & 우 \\
\hline 4 & $100 \mathrm{mg} A \mathrm{~A}$ & 145 & 175 & 461 & 우 \\
\hline 5 & $100 \mathrm{mg} \mathrm{AA}$ & 131 & 154 & $-t$ & $\dot{q}$ \\
\hline 6 & $100 \mathrm{mg} \mathrm{AA}$ & 140 & 162 & $-t$ & $\delta$ \\
\hline $7 \ddagger$ & $2.5 \mathrm{mg}$ PGE-2 & 145 & 148 & 410 & $\sigma($ dead) \\
\hline 8 & $2.5 \mathrm{mg}$ PGE-2 & 136 & 138 & 295 & 웅 \\
\hline 9 & $2.5 \mathrm{mg}$ PGE-2 & 141 & 146 & 320 & $\partial x($ dead $)$ \\
\hline $10 \ddagger$ & $2.5 \mathrm{mg}$ PGE-2 & 149 & 151 & 400 & 우 \\
\hline 11 & None & 143 & 156 & 410 & $a^{2}$ \\
\hline 12 & None & 148 & 175 & 461 & 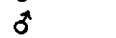 \\
\hline
\end{tabular}

* Extra-amniotic injection of $10 \mathrm{ml}$ Hyskon with or without PGE-2 or arachidonic acid (AA). $\dagger$ Infant not weighed at birth.

¥ Leakage of 3-5 ml fluid occurred, leaving an effective amount of about 1 mg PGE $_{-2}$. 
The concentrations of PGE, PGF and PGFM in maternal peripheral plasma are shown in Table 2. The first blood samples were collected after insertion of the catheter into the amniotic sac. In most instances there was a rise of PGE, PGF and PGFM in maternal plasma following the distension of the vagina, manipulation of the cervix and insertion of the catheter extra-amniotically. No further increase was observed after injection of $100 \mathrm{mg}$ arachidonic acid, but PGE and PGFM concentrations in maternal plasma had increased by 30 min after injection of PGE-2.

There was no change in PGE, PGF or PGFM concentrations in amniotic fluid after insertion of the extra-amniotic catheter or injection of arachidonic acid. However, levels of all three PGs were raised after treatment with PGE-2. In the monkey (No. 9) treated with PGE-2 which did not give birth within $48 \mathrm{~h}$, the concentrations of PGE, PGF and PGFM in amniotic fluid were still higher (Table 2) than those (Nos 5 and 6) given arachidonic acid.

Table 2. The concentrations of PGE, PGF and PGFM in maternal saphenous vein plasma and amniotic fluid before and after extra-amniotic injection of $100 \mathrm{mg}$ arachidonic acid (AA) or $2.5 \mathrm{mg}$ PGF-2

\begin{tabular}{|c|c|c|c|c|c|c|c|c|c|c|c|}
\hline \multirow{3}{*}{$\begin{array}{l}\text { Hormone } \\
(\mathrm{pg} / \mathrm{ml})\end{array}$} & \multirow[b]{3}{*}{ Treatment } & \multirow[b]{3}{*}{ Monkey } & \multicolumn{5}{|c|}{ Maternal plasma } & \multicolumn{4}{|c|}{ Amniotic fluid } \\
\hline & & & \multicolumn{2}{|c|}{$\begin{array}{l}\text { Catheter } \\
\text { insertion }\end{array}$} & \multicolumn{3}{|c|}{ After injection } & \multicolumn{2}{|c|}{$\begin{array}{l}\text { Catheter } \\
\text { insertion }\end{array}$} & \multicolumn{2}{|c|}{$\begin{array}{c}\text { After } \\
\text { injection }\end{array}$} \\
\hline & & & Before & After & $30 \mathrm{~min}$ & $24 \mathrm{~h}$ & $48 \mathrm{~h}$ & Before & After & $30 \mathrm{~min}$ & $48 \mathrm{~h}$ \\
\hline \multirow[t]{4}{*}{ PGE } & AA & 5 & 1317 & 917 & 834 & 606 & 716 & 542 & 667 & 898 & 765 \\
\hline & AA & 6 & 681 & 1624 & 798 & 920 & 2496 & 1176 & 940 & 1022 & 1169 \\
\hline & PGE-2 & 9 & 981 & 1173 & 1812 & -* & 989 & 1773 & 2227 & 33309 & 12568 \\
\hline & PGE-2 & 10 & 963 & 1432 & 12268 & $-*$ & $\mathrm{P} \dagger$ & 2380 & 3877 & 35767 & $\mathrm{P} \dagger$ \\
\hline \multirow[t]{4}{*}{ PGF } & AA & 5 & 73 & 162 & 204 & 56 & 76 & 82 & 194 & 319 & 100 \\
\hline & $\mathbf{A A}$ & 6 & 199 & 560 & 125 & 164 & 1047 & 239 & 143 & 257 & 167 \\
\hline & PGE-2 & 9 & 232 & 306 & 255 & $-*$ & 134 & 199 & 222 & 1474 & 1825 \\
\hline & PGE-2 & 10 & 1033 & 501 & 1496 & $-*$ & $\mathbf{P} \uparrow$ & 415 & 403 & 2608 & P† \\
\hline \multirow[t]{4}{*}{ PGFM } & AA & 5 & 690 & 877 & 874 & 407 & 413 & 422 & 589 & 642 & 504 \\
\hline & $\mathbf{A A}$ & 6 & 362 & 1293 & 1081 & 538 & 951 & 607 & 491 & 489 & 508 \\
\hline & PGE-2 & 9 & 795 & 1916 & 4129 & $-*$ & 695 & 552 & 454 & 3088 & 2229 \\
\hline & PGE-2 & 10 & 435 & 1270 & 5088 & -* & $\mathrm{P} \dagger$ & 5544 & 5970 & 8169 & Pt \\
\hline
\end{tabular}

* No sampie.

$\dagger \mathbf{P}=$ post partum.

\section{Discussion}

These results demonstrate that the extra-amniotic route may be used to test the effects of substances on myometrial activity because the procedure itself did not result in premature delivery. Uterine activity was probably caused by the PGE-2 and was the cause of the leakage of Hyskon in 2 monkeys, although such leakage did not prevent the successful induction of parturition and as little as $1 \mathrm{mg}$ PGE-2 given extra-amniotically is therefore sufficient to induce parturition in the rhesus monkey. These results suggest that the monkey uterus may be less sensitive than the human uterus to exogenous prostaglandins since 240-480 $\mu$ g PGE-2 given extra-amniotically can successfully induce labour within $24 \mathrm{~h}$ in man (Calder, Embrey \& Tait, 1977).

Mitchell, Poyser \& Wilson (1977) have shown that about 1-3\% of arachidonic acid released by uterine homogenates of the guinea-pig is available for prostaglandin synthesis. On this basis the $1 \mathrm{mg}$ arachidonic acid administered in the present study may not have been sufficient to induce parturition. However, since $1 \mathrm{mg}$ PGE-2 successfully induced parturition it was considered that $100 \mathrm{mg}$ arachidonic acid should have been sufficient. It is possible that the arachidonic acid failed to reach the sites of PG synthesis in the uterus, but we consider this explanation of the failure to induce parturition to be unlikely. These results differ from those reported by Schultz, McDonald \& Johnson (1974) who ter- 
minated pregnancy in women by intra-amniotic injection of $1 \mathrm{~g}$ arachidonic acid. However, autooxidation of arachidonic acid to prostaglandin can occur and hence enough primary PGs may have been formed in the amniotic fluid to cause labour in these women.

We conclude that the availability of arachidonic acid is not the only rate-limiting step in the formation of primary PGs between 130-150 days of pregnancy in the rhesus monkey. At this time the concentrations of prostaglandins in amniotic fluid are low, and we suggest that PG synthesis is also low or suppressed because injection of arachidonic acid fails to induce premature parturition or to increase the concentrations of PGE, PGF or PGFM in amniotic fluid or maternal peripheral plasma. Shortly before term the PG synthesis increases and higher concentrations of PGs are found in amniotic fluid (Mitchell et al., 1976). We consider it probable that the conceptus suppresses PG synthetase activity throughout most of pregnancy, thus preventing uterine activity. The trigger for parturition may, therefore, be the removal of this suppression. It has been suggested that the agent effecting the suppression of PG synthesis may be placental lactogen (Thorburn, 1977), but an endogenous inhibitor of PG synthesis has been found in the $\alpha$-globulin fraction of human plasma (Saeed et al., 1977). Such a substance could be the pregnancy-associated $\alpha_{2}$-globulin which has been localized immunocytochemically in the cytoplasm of the decidual cell in human endometrium obtained at Caesarean section (Horne, Bohn \& Towler, 1976).

In addition to the removal of this suppression, PG synthesis may be stimulated by an increase in the concentration of oestrogen (Challis et al., 1977) and of oxytocin (Seppälä, Aho, Tissari \& Rouslahti, 1972) in amniotic fluid. It is, however, possible that the low concentrations of primary PGs could be associated with the synthesis of PGI-2 which may inhibit myometrial activity. This association could be assessed by measuring the concentration of 6-oxo-prostaglandin F-1 $\alpha$ (Jones, Poyser \& Wilson, 1977) in amniotic fluid. In addition, the decidua in the rhesus monkey can produce thromboxane B-2 in vitro (Mitchell, Hicks, Thorburn \& Robinson, 1978b) and the arachidonic acid could therefore act as a substrate for thromboxane synthesis.

We thank Mrs E. J. Kingston and Mrs L. Clover for expert technical assistance; Professor G. S. Dawes, Dr F. Burnett and Dr G. Jenkin for their interest in this work; Dr K. T. Kirton and Dr J. E. Pike (Upjohn Co., Kalamazoo, U.S.A.) and Dr M. Withnall (May \& Baker Co. Ltd, Dagenham, U.K.) for prostaglandin antisera and standards. G.D.T. was a member of the External Scientific Staff of the M.R.C. which also supported the work, and M.D.M. acknowledges receipt of the Staines Medical Fellowship (Exeter College, Oxford).

\section{References}

CAlder, A., Embrey, M.P. \& TAIT, T. (1977) Ripening of the cervix with extra-amniotic prostaglandin $E_{2}$ in viscous gel before induction of labour. Br.J. Obstet. Gynaec. 84, 264-268.

Challis, J.R.G., Davies, I.J., BenirschKe, K., HendRickX, A.G. \& RYAN, K.J. (1974) The concentrations of progesterone, estrone and estradiol$17 \beta$ in the peripheral plasma of the rhesus monkey during the final third of gestation and after the induction of abortion with $\mathrm{PGF}_{2 \alpha}$. Endocrinology 95, $547-553$.

Challis, J.R.G., Robinson, J.S. \& Thorburn, G.D. (1976) Fetal and maternal endocrine changes during pregnancy and parturition in the rhesus monkey. In The Fetus and Birth (Ciba Fndn. Symp. No. 47), pp. 211-227. Eds J. Knight \& M. O'Connor, ElsevierExcerpta Medica-North-Holland, Amsterdam.

Challis, J.R.G., Hartley, P., Johnson, P., Patrick, J.E., ROBINSON, J.S. \& THORBURN, G.D. (1977) Steriods in the amniotic fluid of the rhesus monkey (Macaca mulatta). J. Endocr. 73, 355-363.
GuSTAVII, B. (1973) Studies on the mode of action of intra-amniotically and extra-amniotically injected hypertonic saline in therapeutic abortion. Acta obstet. gynec. scand., Suppl. 25.

HoRne, C.H.W., BoHN, H. \& TOWleR, C.M. (1976) Pregnancy-associated $\alpha_{2}$ glycoprotein. In Plasma Hormone Assays in Evaluation of Fetal Wellbeing, pp. 147-173. Ed. A. Klopper. Churchill-Livingstone, Edinburgh,

Jones, R.L., Poyser, N.L. \& Wilson, N.H. (1977) Production of 6-oxo-prostaglandin $\mathrm{F}_{1 \alpha}$ by rat, guinea-pig and sheep uteri in vitro. Br. J. Pharmac. 59, 436P437P.

Karim, S.M.M., Hillier, K. \& Devlin, J. (1968) Distribution of prostaglandin $E_{1}, E_{2}, F_{1 \alpha}$ and $F_{2 \alpha}$ in some animal tissues. J. Pharm. Pharmac. 20, 749-753.

Keirse, M.J.N.C. \& Turnbull, A.C. (1976) The fetal membranes as a possible source of amniotic fluid prostaglandins. Br. J. Obstet. Gynaec. 83, 146151.

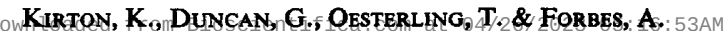


(1971) Prostaglandins and reproduction in the rhesus monkey. Ann. N.Y. Acad. Sci. 180, 445-455.

Kirton, K.T., Pharriss, B.B. \& Forbes, A.D. (1970) Some effects of prostaglandin $E_{2}$ and $F_{2 \alpha}$ on the pregnant rhesus monkey. Biol. Reprod. 3, 163-168.

Kunze, H. \& VoGT, W. (1971) Significance of phospholipase A for prostaglandin formation. Ann. N.Y. Acad. Sci. 180, 123-125.

Manaugh, L.C. \& Novy, M.J. (1976) Effects of indomethacin on corpus luteum function and pregnancy in rhesus monkeys. Fert. Steril. 27, 588-598.

Mitchell, M.D. \& Flint, A.P.F. (1978) Prostaglandin production by intra-uterine tissues from periparturient sheep: use of a superfusion technique. $J$. Endocr. 76, 111-121.

Mitchell, M.D., PAtrick, J.E., Robinson, J.S., Thorburn, G.D. \& Challis, J.R.G. (1976) Prostaglandins in the plasma and amniotic fluid of rhesus monkeys during pregnancy and after intra-uterine foetal death. J. Endocr. 71, 67-76.

Mitchell, S., Poyser, N.L. \& Wil.son, N.H. (1977) Effect of p-bromophenacyl bromide, an inhibitor of phospholipase $\mathbf{A}_{2}$, on arachidonic acid release and prostaglandin synthesis by the guinea-pig uterus in vitro. Br. J. Pharmac. 59, 107-113.

Mitchell, M.D., Flint, A.P., Bibby, J., BRUNT, J., ARNold, J.M., ANDERSON, A.B.M. \& TURNBULl, A.C. (1978a) Plasma concentrations of prostaglandins during late human pregnancy: influence of normal and pre-term labour. J. gen. Endocr. Metab. (in press).

Mitchell, M.D., Hicks, B.R., Thorburn, G.D. \& RoBinson, J.S. (1978b) Production of thromboxane $B_{2}$ by intra-uterine tissues from late pregnant rhesus monkeys. J. Endocr. (in press).

Novy, M.J., CoOK, M.J. \& MaNAUgh, L.C. (1974) Indomethacin block of normal onset of parturition in primates. Am. J. Obstet. Gynec. 118, 412-416.

Saeed, S.A., McDonald-Gibson, W.J., Cuthbert, J., Copas, J.L., Schneider, C., Gardiner, P.J., Butt, N.M. \& COLlIER, H.O.J. (1977) Endogenous inhibitor of prostaglandin synthetase. Nature, Lond. 270, 32-36.

Schultz, F.M., MacDonald, P.C. \& Johnson, J.M. (1974) Arachidonic acid in human amniotic fluid and its relationship to labor. Gynaecol. Invest. 5, 62.

Schwarz, B.E., Schultz, F.M., MacDonald, P.C. \& JoHNSON, J.M. (1976) Initiation of human parturition. IV Demonstration of phospholipase $A_{2}$ in the lysosomes of human fetal membranes. Am. J. Obstet. Gynec. 125, 1089-1092.

SePpälä, M., Aho, I., Tissari, A. \& Rouslahti, E. (1972) Radioimmunoassay of oxytocin in the amniotic fluid, fetal urine and meconium during late pregnancy and delivery. Am. J. Obstet. Gynec. 114, 788-795.

ThORBURN, G.D. (1977) Fetal hormones and the initiation of labour. Ann. Rech. Vet. 8, 428-437.

Received 28 March 1978 